|| Print ISSN: 2589-7837 || Online ISSN: 2581-3935 ||

International Journal of Medical Science and Diagnosis Research (IJMSDR)

Available Online at www.ijmsdr.com

NLM (National Library of Medicine ID: 101738824)

Case Report

Volume 5, Issue 3; March: 2021; Page No. 50-52

\title{
TWO DIFFERENT CASES OF NEW ONSET NEUROPATHY AFTER PANCREATIC TRANSPLANTATION
}

\author{
Dr. Vedhanayagam Nagarathinam ${ }^{1}$, Dr. Dhanaraj ${ }^{2}$, Dr. Nikhil ${ }^{3}$, Dr. Anil Vaidya ${ }^{4}$ \\ ${ }^{1}$ Consultant Neurologist, Kongunad Hospitals, Tatabad, Coimbatore \\ ${ }^{2}$ Consultant Neurologist, Apollo Main Hospitals, Greams Road, Chennai \\ ${ }^{3}$ Apollo Main Hospitals, Greams Road Chennai \\ ${ }^{4}$ Apollo Main Hospitals, Greams Road Chennai
}

Conflicts of Interest: Nil

Corresponding author: Dr. Vedhanayagam Nagarathinam

DOI: https://doi.org/10.32553/ijmsdr.v5i3.771

\begin{abstract}
: neuropathy

\section{Introduction:}

Pancreatic transplantation is the most logical treatment for diabetes mellitus and most of the type-one diabetes mellitus patients are known to have symptomatic peripheral neuropathy prior to the pancreatic transplantation. It is known that these symptoms improve after pancreatic transplantation. ${ }^{1,2}$ New onset neuropathy following pancreatic transplant is extremely rare, it might occur secondary to an independent problem or drugs which are given for immuno-suppression. This paper describes two different patients with peripheral neuropathy after pancreatic transplantation.
\end{abstract}

Presenting two different cases of new onset peripheral neuropathy after pancreatic transplantation. One demyelinating in type which is rare in literature, recovered spontaneously and other one is axonal in type improved with early aggressive intra-venous immunoglobulin therapy.

Keywords: Tacrolimus, Post transplant, IV-IG(Intravenous immunoglobulin), Demyelinating and Axonal

\section{Case Report 1:}

A 22 year male presented with subacute onset, progressive symmetric weakness and numbness of all four limbs for two month duration. On clinical examination patient had moderate weakness (walks with someone's help) and graded sensory loss of all modalities involving both upper and lower limbs, with no clinical evidence of autonomic involvement.

He was a known type one diabetes for ten years on insulin therapy. He had no symptoms of peripheral neuropathy, retinopathy or nephropathy before transplant. He underwent isolated pancreatic transplantation, two months prior to the onset of these symptoms. He received booster dose of HBV vaccine preceding surgery and $15 \mathrm{mg}$ of Adalimumab on the day of surgery. Post operatively he was on mycophenolate 1 gram/day and tacrolimus $1.5 \mathrm{mg} /$ day. $\mathrm{He}$ was ambulant until this presentation. Electrophysiological study and other tests were done to evaluate the cause of neuropathy are mentioned in Table 1. Tacrolimus was discontinued and an alternative immunosuppression cyclosporine was initiated. Patient had progressive improvement in a week without any active medical intervention.

\section{Case Report 2:}

A 23 year old gentleman, presented with sub-acute onset,progressive weakness and paraesthesias of all four limbs of one month duration. Clinical examination revealed moderate weakness of all four limbs with bilateral foot drop and sluggish deep tendon reflexes along with graded sensory loss for all modalities.

He was a known type one diabetic for 10 years on insulin therapy, He also had no sympoms of peripheral neuropathy,retinopathy or nephropathy before transplant. He underwent isolated pancreatic transplant five months prior to the onset of the present symptoms. He received a booster dose of $\mathrm{HBV}$ vaccine preceding surgery, and $15 \mathrm{mg}$ of Adalimumab on the day of surgery. Post operatively he was on mycophenolate $1 \mathrm{~g} /$ day and tacrolimus $1 \mathrm{mg} /$ day. Electrophysiological study and other investigations were mentioned in Table 1.Tacrolimus was stopped and cyclosporine was initiated as an alternative. However the symptoms deteriorated further hence treated with Intra-venous immunoglobulin for 5 days. 
Patient showed improvement in weakness and walks independently within a month.

Table 1: Summary and Investigations

\begin{tabular}{|c|c|c|c|}
\hline SUMMARY & \multicolumn{2}{|l|}{ CASE I } & CASE II \\
\hline Age,sex & \multicolumn{2}{|l|}{22 year, Male } & 23 year, Male \\
\hline $\begin{array}{l}\text { Duration of } \\
\text { mellitus }\end{array}$ & \multicolumn{2}{|l|}{10 years } & 10 years \\
\hline Glycemic control & \multicolumn{2}{|l|}{ Well controlled } & Poorly controlled \\
\hline Pre-operative evaluation & \multicolumn{2}{|l|}{ No neurologic deficit } & $\begin{array}{ll}\text { No } & \text { neurologic } \\
\text { deficit } & \end{array}$ \\
\hline 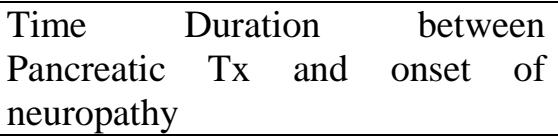 & \multicolumn{2}{|l|}{2 Months } & 5 Months \\
\hline Pre-op vaccine & \multicolumn{2}{|c|}{$\mathrm{HBV}$} & HBV \\
\hline Per-op medication & \multicolumn{2}{|c|}{ Adalimumab15mg single dose } & $\begin{array}{l}\text { Adalimumab } 15 \mathrm{mg} \\
\text { single dose }\end{array}$ \\
\hline Post-op immunosuppression: & \multicolumn{2}{|l|}{ Tacrolimus $1.5 \mathrm{mg} /$ day } & $\begin{array}{l}\text { Tacrolimus } \\
1.5 \mathrm{mg} / \text { day }\end{array}$ \\
\hline Serum Tacrolimus & \multicolumn{2}{|l|}{$6 \mathrm{ng} / \mathrm{dl}(5-15 \mathrm{ng} / \mathrm{ml})$} & $\begin{array}{l}8.1 \mathrm{ng} / \mathrm{dl} \quad(5-15 \\
\mathrm{ng} / \mathrm{ml})\end{array}$ \\
\hline Serum B12 & $355 \mathrm{pg}(200-900 \mathrm{pg})$ & 416 pg(200-900pg) & \\
\hline Serum TSH & $\begin{array}{l}4.5 \mathrm{ng} / \mathrm{dl}(0.45- \\
4.5 \mathrm{mU} / \mathrm{L})\end{array}$ & $\begin{array}{l}4.7 \mathrm{ng} / \mathrm{dl} \\
(0.45-4.5 \mathrm{mU} / \mathrm{L})\end{array}$ & \\
\hline ANA,pANCA,cANCA & Negative & Negative & \\
\hline Serum Protein Electrophoresis & Normal & Normal & \\
\hline CMV-PCR & Negative & Negative & \\
\hline CSF Analysis: & $\begin{array}{l}\text { Cell Count: No cells } \\
\text { Type:-Nil } \\
\text { Protein: } 37 \mathrm{mg} / \mathrm{dl}\end{array}$ & $\begin{array}{l}\text { Cell Count: } 10 \\
\text { Type: Lymphocytes } \\
\text { Protein:59 mg/dl }\end{array}$ & \\
\hline Electro-physiology: & $\begin{array}{l}\text { Demyelinating } \\
\text { polyradiculoneuropathy }\end{array}$ & $\begin{array}{l}\text { Severe sensorymotor } \\
\text { polyradiculoneuropathy }\end{array}$ & \\
\hline Treatment given: & $\begin{array}{l}\text { a)Tacrolimus changed } \\
\text { to cyclosporine } \\
\text { b)Supportive care }\end{array}$ & $\begin{array}{l}\text { a)Tacrolimus changed to } \\
\text { cyclosporine } \\
\text { b)Intravenous } \\
\text { immunoglobulin } \\
0.4 \mathrm{~g} / \mathrm{kg} / \text { day for } 5 \text { days }\end{array}$ & \\
\hline Outcome: & $\begin{array}{l}\text { Improved } \\
\text { (within a week) after } \\
\text { discontinuing } \\
\text { tacrolimus }\end{array}$ & $\begin{array}{l}\text { Improved } \\
\text { (within 30days) after } \\
\text { discontinuing tacrolimus } \\
\text { and early aggressive } \\
\text { immunomodulation with } \\
\text { IVIG }\end{array}$ & \\
\hline
\end{tabular}

\section{Discussion:}

New onset neuropathy after transplant procedure is very rare.Etiology for these scenarios can be

(i) Surgical procedure related nerve injury,

(ii) Focal compressive neuropathy,

(iii) Opportunistic cytomegalovirus (CMV) related neuropathy,

(iv) Nutritional deficiency, (v) Graft versus host disease (GVHD) manifesting as acute/chronic inflammatory demyelinating polyneuropathy (AIDP/CIDP),

(vi) Critical illnesss myoneuropathy and

(vii) Immunosuppressive agents used after transplant ${ }^{3,4}$

In both of our cases, there was no prior neurological illness or any evidence of graft vs host reaction on 
follow up visits. Clinically and by investigations there was no evidence of nutritional deficiency. Post transplant CMV related neuropathy can be a possibility ${ }^{4}$ but in both cases CMV PCR test was negative.

The other possibility to be considered would be a neuropathy secondary to the immunosuppressive agents which are used in these scenarios. In our cases, single dose of adalimumab was used per-operatively but this drug and the dose provided is not commonly known to cause peripheral neuropathy ${ }^{5}$.

The tacrolimus related neuropathy was the next possibility. The time between initiation of tacrolimus and onset of symptoms varied between 8 days to 3 weeks. Tacrolimus-related polyneuropathy patients had improvement after switching it to an alternative immunosuppression ${ }^{3}$. Hence in both these patients it was stopped and an alternative immunosuppressive agent was initiated. It is known that exceeding levels of tacrolimus in serum are known to cause peripheral neuropathy ${ }^{6}$. But in both cases the serum values of this drug were well within therapeutic range,ie not exceeding the toxic range. As per Gunnela Norden et al case report, even with therapeutic levels of tacrolimus peripheral neuropathy can be expected to occur $^{7}$.Hence,high index of suspicion will help in early diagnosis and better management of Tacrolimus related neuropathy Tacrolimus related neuropathy are thought to be due to its direct neural toxic effect ${ }^{9-12}$. Predominantly, they are axonal in type and most of them recover gradually after stopping tacrolimus ${ }^{3,9-12,}$ .Eventhough, few of demyelinating neuropathy also had been reported in western literature ${ }^{10}$. Our first case presenting with demyelinating type of neuropathy which improved gradually after discontinuing tacrolimus without any further intervention.The second patient with axonal neuropathy, despite of stopping tacrolimus deteriorated quickly and required early aggressive therapeutic intervention with immunoglobulins. Hence we postulate, that in an already vulnerable patient,we need to keep track of the disease progression for early aggressive therapeutic intervention with IVIG .

\section{Conclusion:}

Even therapeutic levels of tacrolimus can produce both demyelinating and axonal type of progressive peripheral neuropathy. Early discontinuation and switching it to an alternative safer drug would be the first move, followed by, to keep track of the disease progression for early aggressive therapeutic intervention with intravenous immunoglobulin (IVIG).

\section{References:}

1. William R. Kennedy,et al. Effects of Pancreatic Transplantation on Diabetic Neuropathy. N Engl J Med 1990; 322:1031-1037

2. Allen RD1, Al-Harbi IS.et al, Diabetic neuropathy after pancreas transplantation: determinants of recovery. Transplantation. 1997 Mar 27;63(6):830-8

3. Annick De Weerdt,et al. Tacrolimus-related polyneuropathy: Case report and review of the literature. Clinical Neurology and Neurosurgery 110 (2008) 291-294

4. Fishman JA, Rubin RH. Infection in organtransplant recipients. N Engl J Med. 1998 Jun 11. 338(24):1741-51

5. Xavier Bosch, Albert Saiz,et al. Monoclonal antibody therapy-associated neurological dis.NatureReviews Neurology 7, 165-172 (March 2011).

6. Geru.Wu,Francis LW,et al.Tacrolimus induced encephalopathy and polyneuropathy in a renal transplant recipient.BMJ Case Rep 2013.

7. Gunnela Nordén, Michael Olausson et al. A case of painful progressive peripheral neuropathy after successful pancreas transplantation. Journal of Diabetic Complications. Volume 5, Issue 4, October-December 1991, Pages 249-251

8. McMaster DF, Mirza. DF, et al.Therapeutic drug monitoring of Tacrolimus in clinical transplantation.Ther.Drug.Monit 1995 Dec;17(6);602

9. Wilson JR, Conwit RA, Eidelman BH, Starzl T, Abu-Elmagd K. Sensorimotor neuropathy resembling CIDP in patients receiving FK506. Muscle Nerve 1994;17:528-32.

10. Bronster DJ,Yonover P, Stein J, Scelsa SN, Miller CM, Schreiner PA. Demyelinating sensorimotor polyneuropathy after administration of FK506. Transplantation 1995;59:1066-8.

11. Fujii N, Ikeda K, Koyama M, et al. Calcineurin inhibitor-induced irreversible neuropathic pain after allogeneic hematopoietic stem cell transplantation. Int J Hematol 2006;83:459-61

12. Schreiber SL, Crabtree GR. The mechanism of action of cyclosporin $\mathrm{A}$ and FK506. Immunol Today 1992;13:136-42 